\title{
Small Intestine Cancer Clinical TNM Finding v8
}

National Cancer Institute

\section{Source}

National Cancer Institute. Small Intestine Cancer Clinical TNM Finding v8. NCI Thesaurus. Code C133826.

A clinical finding about one or more characteristics of small intestine cancer, following the rules of the TNM AJCC V8 classification system. 